\title{
MIS 5e sea-level proxies in the eastern Mediterranean coastal region
}

\author{
Barbara Mauz ${ }^{1,2}$, Dorit Sivan ${ }^{3}$, Ehud Galili ${ }^{4}$ \\ ${ }^{1}$ School of Environmental Sciences, University of Liverpool, Liverpool, L69 7ZT, UK \\ ${ }^{2}$ Department of Geology and Geography, University of Salzburg, Salzburg, 5020, Austria \\ $5 \quad{ }^{3}$ Maritime Civilizations Department, L. Charney School of Marine Sciences, University of Haifa, Israel \\ ${ }^{4}$ Zinman Institute of Archaeology, University of Haifa, 199 Aba-Khoushi Avenue, Mount Carmel, Haifa, 3498838, Israel
}

Correspondence to: Barbara Mauz (mauz@liverpool.ac.uk)

\begin{abstract}
Mediterranean 'raised beaches' were subject to Quaternary research since the early years of the $20^{\text {th }}$ century. The uniqueness of a warm-loving molluscs fauna immigrating into the Mediterranean made the coastline a prime subject for

10 studying Quaternary sea-level changes. Today, we have a detailed picture of this historically important coastline characterised by tectonically dormant coastal zone alternating with zones that are subject to subsidence or uplift. As part of the Word Atlas of last interglacial shorelines (WALIS) database we compiled 21 MIS 5e proxies for the eastern Mediterranean area available at http://doi.org/10.5281/zenodo.4274178 (Israel; Sivan and Galili, 2020) and at http://doi.org/10.5281/zenodo.4283819 (Turkey, Egypt, Tunisia; Mauz, 2020). All these datapoints are sea-level indicators

15 of variable quality situated between $-1 \pm 4 \mathrm{~m}$ and $7 \pm 2 \mathrm{~m}$ resulting in a reconstructed MIS 5e palaeo-sea level situated between $-1 \pm 4 \mathrm{~m}$ and $13 \pm 10 \mathrm{~m}$.
\end{abstract}

\section{Introduction}

The eastern Mediterranean area (Fig. 1) is a remain of the western Neotethys Ocean (Hafkenscheid and Spakman, 2006) which formed when the Indian Ocean gateway closed during the Miocene (Bialik et al., 2019). It contains the oldest oceanic crust on earth (Granot, 2016) which is actively subducting beneath the Aegean Sea (Crete, Peleponnese peninsula) and the Ionian Sea (Calabria). The oceanic crust is part of the northeast moving African plate and the continental part of this plate is a passive continental margin. The coasts of the eastern Mediterranean are therefore situated on earth's crustal segments that are, on late Quaternary time scales, actively deformed, slowly deformed or dormant. Because the eastern Mediterranean has a long history of geoscientific work the actively deformed areas, such as the Gulf of Corinth, Crete and Cyprus are very well studied (e.g., McPhee and Hinsbergen, 2019; McNeill et al., 2018). These studies used, amongst other features, the relatively well-preserved last interglacial (LIG) marine terraces. On the other side, the coast of the African passive continental margin received attention through Quaternary scientist who aimed, in the first instance at least (e.g., Gignoux 2013), to carry forward the biostratigraphy of the late Tertiary owing to the fauna-rich coastal deposits. Today, our understanding of the geodynamics (e.g., Nocquet, 2012) enables us to attribute the eastern Mediterranean coastal zones to large-scale geological 
30 structures (Fig. 1). This in turn enables us to separate shoreline data generated to unravel tectonic processes from sea-level data generated to reconstruct the LIG sea level and the associated ice volumes, eustacy and related GIA processes. In this paper we describe previously published sea-level indicators on the basis of standards first developed by van de Plassche (1986) and Shennan, (1986), recently compiled in Shennan et al. (2015) and implemented by WALIS (https://warmcoasts.eu/world-atlas.html). We thereby contribute to the WALIS database described in Rovere et al. (2020)

35 available open-access at: DOI 10.5281/zenodo.4274178 for Israel (Sivan and Galili, 2020) and DOI 10.5281/zenodo.4283819 for the remaining eastern Mediterranean (Mauz, 2020).

\subsection{Literature overview}

The overview follows the clockwise spatial arrangement of large-scale geological structures in the eastern Mediterranean (Fig. 1) starting in the north. For the sake of clarity, we use names of eastern Mediterranean sub-basins supported by names

40 of nations. In terms of time we review literature which studied the "Tyrrhenian", a Mediterranean chronostratigraphic stage of the late Pleistocene that broadly encompasses the MIS 5 stage (Gibbard and Cohen, 2008). Historically, the Tyrrhenian stage has been identified on the basis of the so-called "Senegalese" fauna (Gignoux, 1913) which is an assemblage of warmloving, shallow marine molluscs originating from the tropical Atlantic with the gastropod Strombus bubonius being its leading fossil. The Senegalese fauna immigrated into the Mediterranean during MIS 5 and disappeared with average sea-

45 surface temperatures falling below $20^{\circ} \mathrm{C}$ (Sessa et al., 2013). Therefore, the assemblage disappeared most probably $\sim 115 \mathrm{ka}$, but may have remained until $\sim 80 \mathrm{ka}$ in niches along the warm north African coast.

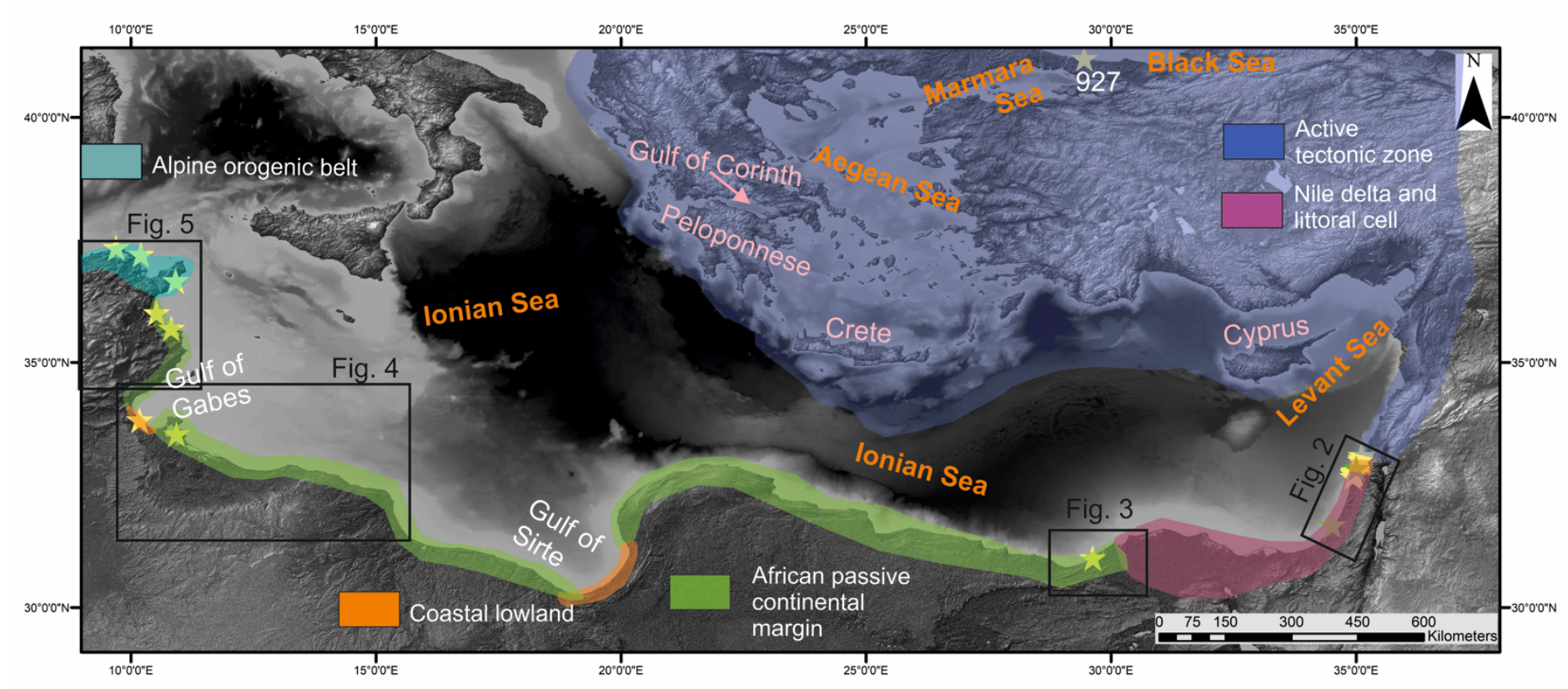


Fig. 1. The eastern Mediterranean and its coastal zones established for the purpose of this review. The zones are delimited according to the dominant geodynamic regime associated with the closure of the Tethys ocean (e.g., McPhee and van

50 Hindsbergen, 2019), the African passive continental margin (Nocquet, 2012), the zone affected by the Nile discharge (Emery and Neev, 1960; Davis et al., 2012) and the morphological lowlands which are graben or rift basins with minor or absent tectonic activity during the late Quaternary. The Gebco data were obtained from GEBCO Compilation Group (2020) GEBCO 2020 Grid (doi:10.5285/a29c5465-b138-234d-e053-6c86abc040b9). SRTM data were obtained from http://srtm.csi.cgiar.org (Jarvis et al., 2008).

$55 \quad$ 1.1.1 Active tectonic zone

Ionian Sea (Peloponnese peninsula, Greece) - this area is situated adjacent to the Hellenic trench and the Kephalonia fault both being part of the Hellenic subduction zone. Athanassis and Foutoulis (2013) identify MIS 5 shell-rich littoral deposits on a "platform" with a palaeo-shoreline situated at ca 40 - $60 \mathrm{~m}$ altitude.

Ionian Sea (Corinth Gulf) - the gulf is a marginal sea connected to the Ionian Sea through two 50-60 m deep sills. It is

60 affected by high to very high extension rates and associated uplift of coastal zones. A suite of marine terraces occurs on the southeast coast of the Gulf (Vokha plain) which attracted many researchers owing to the large number of terrace levels (16 terraces; de Gelder et al., 2019), their well-preserved topographic expression and coastal sediment cover. The early studies focused on the relationship between sea-level highstands and terrace elevation (e.g., Keraudren and Sorel, 1987; Collier, 1990) followed by studies looking at the terraces, their sediment cover and associated ages and at structural implications

65 with the seminal paper published by Armijo et al. (1996). The researchers' interest focused on the understanding of the Corinth rift (e.g., Gawthorpe et al., 2018) and we refer the reader to De Gelder et al. (2019) for the most recent study of the terraces and to McNeill et al. (2018) for the interplay between rifting, sediment routing, climate and sea level.

Marmara Sea (Turkey) - this is a marginal sea connected to the Aegean Sea through a ca $70 \mathrm{~m}$ deep sill (Dardanelles). Two major branches of the North Anatolian fault (NAF) delimit the Marmara basin to the north and south forming the Marmara

70 transtensional basin (Jenkins et al., 2020). The northern NAF strand creates deep tectonic depressions separated by structural highs (Jenkins et al., 2020). High rates of NAF motion ( $20 \mathrm{~mm} / \mathrm{a}$ ) progressively increasing westward (Bulkan et al., 2020) and associated earthquakes makes the area a prime subject of hazard studies. Studying Pleistocene marine terraces in this area aims therefore at determining uplift rates and, in addition, the hydrodynamic history between the Black Sea and the Aegean Sea. Yaltirak et al. (2002) studied the marine terraces along the Dardanelles coast and finds the LIG terrace at 38-22

$75 \mathrm{~m}$ and at 9-0 $\mathrm{m}$.

Aegean Sea (Crete) - the Crete island is a subaerial forearc above the Hellenic subduction zone and thus, its shorelinerelated features are used to study the geodynamics of the eastern Mediterranean (e.g., Robertson et al., 2019). The studies focus on the south coast of the island where the LIG marine terrace is situated at 160-180 m altitude (Robertson et al., 2019) and at 50-100 m altitude (Gallen et al., 2014). For the most recent study of the terraces see Ott et al. (2019) and references therein. 
Levant Sea (Cyprus) - the Cyprus island is situated above the Cyprean subduction zone. Similar to Crete, its marine terraces and related shoreline features are in the focus of structural geologists in order to understand the geodynamics of the eastern Mediterranean (e.g., McPhee and van Hinsbergen, 2019). Pleistocene deposits were studied by Vita-Finzi (1990; 1993), Zomeni (2012), Poole et al. (1990) and Poole and Robertson, (1991) with the latter two studies showing that the

85 "Tyrrhenian" terrace is situated at $<3 \mathrm{~m}$ on the south coast. On the north coast Galili et al. (2016) find the LIG terrace at 12$17 \mathrm{~m}$ while Palamakumbura et al. (2016) find the same terrace at $4 \mathrm{~m}$ altitude.

Levant Sea (Turkey, Syria, Lebanon) - the northernmost part of the Levant coast (Turkey) is part of the collision zone between the northward moving Arabian Plate, the westward moving Anatolian Plate and the southward moving African plate. There, Tari et al. (2018) studied marine terraces occurring within the Antakya Graben and find the MIS 5e marine terrace at around $50 \mathrm{~m}$ altitude. Further south the coast is situated on the west flank of the sinistral Dead Sea transform fault characterised by coastal mountain ranges, pull-apart basins and graben (Brew et al., 2001). The coastal ranges are bounded by numerous normal and strike slip faults which are a consequence of the branching Dead Sea transform fault (Lebanese Restraining Bend; e.g., Weinberger et al., 2009). Dodonov et al. (2008) studied marine terraces on the Syrian coast and assigned the ones situated at $20-30 \mathrm{~m}$ to MIS 5. The southern boundary between deformed and dormant coastal zone is

95 represented by the Rosh Hanikra fault (Morhange et al., 2006).

Ionian Sea (north Tunisia) - the northernmost coast of Tunisia is part of the Alpine orogenic belt and associated tectonic processes. LIG deposits are part of cliff sections (Wided et al., 2019) or marine terraces. Elmejdoub and Jedoui (2009) show that in NE Tunisia the LIG deposits are part of a marine terrace at $\sim 25 \mathrm{~m}$ altitude.

\subsubsection{Nile littoral cell and Nile delta}

100 Levant Sea (Israel) - The central ("Carmel”) coast is part of the passive continental margin of the African plate which moves southward along the Dead Sea transform fault (e.g., Weinberger et al., 2009). It receives its sediments exclusively through the Nile littoral cell (e.g., Davis et al., 2012) which is a persistent easterly-driven longshore current created by the interplay of winds and Coriolis force. Coastal deposits bearing Strombus bubonius were first described by Issar and Kafri, (1972) and subsequently defined as "Yasaf" member by Sivan et al. (1999). LIG deposits occur on the Galilee coast at elevations 1-2 m

105 (Sivan et al., 2016), in Haifa bay at around -25 m (Fig. 2; Avnaim-Katav et al., 2012), on the Carmel coast at -1 $\mathrm{m}$ up to $7 \mathrm{~m}$ (Galili et al., 2007; 2018) and on the Sharon coast at around - 55 m (Fig. 2; Porat et al., 2003).

\subsubsection{African passive continental margin}

Ionian Sea (Egypt) - the coast sits on the African plate with minor to negligible effects from tectonic movements on the LIG deposits. The coastal plain west of the Nile delta exhibits a series of beach ridges first described and dated by El-Asmar 1994

110 and later by El-Asmar and Wood (2000) and studied by Elshazly et al. (2019). The second ridge behind the modern coastline was attributed to MIS 5e (Fig. 3). 
Ionian Sea (Libya) - The coast from west of Alexandria (Egypt) to east of Tripoli (Libya) is under-studied and Quaternary deposits are only known from Explanatory Booklet provided in association to geological maps. Therein, Hinnawy and Cheshitev (1975) describe the "Gargaresh Formation" of "Tyrrhennian" age which forms an elongated ridge parallel to the 115 modern shoreline (Fig. 4).

Ionian Sea (Tunisia) - the coast is situated on the largest eastern Mediterranean shelf. Around Djerba island the LIG coastal environment is represented by a barrier stretching from Sabratah to the southern Gulf of Gabès (Fig. 4; Jedoui et al., 2003). A barrier also existed north of the Gabès gulf in the Gulf of Hammamet and along the south coast of Cap Bon. Coastal deposits were first systematically described by Paskoff and Sanaville (1983). Hearty (1986) provide the first age for the

120 Monastir site (Fig. 5) through his seminal work on amino acid razemisation correlated to U-series ages. Subsequently, Queslati (1994) and Jedoui et al. (2003) studied the LIG deposits on the south coast situated at 2-6 m altitude. Later, Mauz et al. (2009) studied sedimentological details of the deposits and their ages.

\subsubsection{Coastal lowland}

These coastal zones (Fig. 1) are morphological lowlands. Ongoing subsidence during the Quaternary is possible but not 125 everywhere evident from data.

Black Sea (Turkey) - this area is connected to the Aegean Sea through the $\sim 100 \mathrm{~m}$ deep Bosporus sill. The Turkish Black Sea coast is in most places affected by tectonic uplift of up to $5 \mathrm{~mm} / \mathrm{a}$ with the exception of the Sile site where several mm/a subsidence seems to prevail (Avsar et al., 2017). The GIA contribution to vertical land movements is estimated to $\sim 0-1 \mathrm{~mm} / \mathrm{a}$ (Avsar et al., 2017). Erginal et al. (2017) describes a shell-rich sandstone ("coquinite") at Sile situated within today's beach 130 zone and dated to around $128 \mathrm{ka}$.

Haifa bay, Rosh Hanikra platform (Levant Sea, Israel) - the northern ("Galilee") coast is situated between the Rosh Hanikra fault and the Carmel fault. The Ahihud fault separates the Rosh Hanikra platform from Haifa bay. Avnaim-Katav et al. (2012) report MIS 5e deposits from borehole data in Haifa bay at ca $-25 \mathrm{~m}$. No onshore coeval deposit is reported from this bay (Zviely et al., 2006).

135 Gulf of Sirte (Libya) - the gulf is part of a Cretaceous rift basin undergoing northward tilting and associated subsidence (van der Meer and Cloetingh, 1993). Giglia (1984) describes shallow marine oolitic limestone situated at around $3 \mathrm{~m}$ around 20 $\mathrm{km}$ inland.

Gulf of Gabès (Tunisia) - the gulf is part of the collapsed Jeffara block dominated by normal faulting during the Quaternary (Gharbi et al., 2016). Shape and geometry of the gulf funnels the tidal wave with the consequence that the gulf coast 140 experiences not only the highest tidal range in the Mediterranean (1.5 m; Gzam et al 2016) but also unusual shore-parallel hyrodynamic conditions (Gzam et al 2016). The LIG deposit is part of a beach ridge stretching parallel to the modern coastline at ca $3 \mathrm{~m}$ altitude (Fig. 4). 


\section{Sea-level indicators}

Occurrence and preservation of sea-level indicators on the eastern Mediterranean coast is controlled by the morphology,

145 sediment supply and geological structure of the particular coastal zone as well as by the human demand for coastal resources. Large coastal zones are deprived of indicators, e.g. the frequently cited zone at Monastir (Tunisia; e.g., Kopp et al., 2009). On rocky, sediment-starved coasts erosional indicators such as abrasion platforms and tidal notches prevail while on soft sediment coasts with sufficient sediment supply beach ridges, sandy beaches, barriers and spits prevail. Sediment-starved coasts show abiotic carbonate crusts and lithophaga borings or biotic, reef-like constructions generated by red algae (corallinacea), algal serpulids, coral (Cladocora caespitosa) or vermetids. Some of the indicators can provide small vertical uncertainties, for instance, if the living range of a particular fauna is small or if the sediment facies is well constrained in terms of water depth. For list of indicators see Table 1.

Table 1: RSL indicators reviewed in this study.

\begin{tabular}{|c|c|c|c|c|}
\hline $\begin{array}{l}\text { Name of RSL } \\
\text { indicator }\end{array}$ & Description of RSL indicator & $\begin{array}{l}\text { Description of } \\
\text { RWL }\end{array}$ & $\begin{array}{l}\text { Description } \\
\text { of IR }\end{array}$ & $\begin{array}{l}\text { Indicator } \\
\text { reference(s) }\end{array}$ \\
\hline Marine terrace & $\begin{array}{l}\text { Flat, gently seaward dipping } \\
\text { rock surface bearing a veneer } \\
\text { of coastal sediment and/or } \\
\text { fauna }\end{array}$ & $\begin{array}{l}\text { (Storm wave } \\
\text { swash height }+ \\
\text { Breaking depth) / } \\
2\end{array}$ & $\begin{array}{l}\text { Storm wave } \\
\text { swash height } \\
\text { - Breaking } \\
\text { depth }\end{array}$ & $\begin{array}{l}\text { Rovere et al., } \\
2016\end{array}$ \\
\hline Coastal notch & $\begin{array}{l}\text { Convex-shaped hole carved in } \\
\text { hard rock }\end{array}$ & MSL & $\begin{array}{l}\text { Tidal range }= \\
30-40 \mathrm{~cm}\end{array}$ & $\begin{array}{l}\text { Antonioli et al } \\
2015\end{array}$ \\
\hline Sediment facies & $\begin{array}{l}\text { Coastal conglomerate, } \\
\text { siliciclastic or carbonate sand; } \\
\text { oolitic sand, lagoonal silt and } \\
\text { clay }\end{array}$ & MSL & $\begin{array}{l}\text { backshore to } \\
\text { shoreface (ca } \\
0-10 \mathrm{~m} \text { water } \\
\text { depth) }\end{array}$ & $\begin{array}{l}\text { Miall, 2010; } \\
\text { Reading, } \\
\text { 1986; Mauz et } \\
\text { al. } 2012\end{array}$ \\
\hline $\begin{array}{l}\text { Lithophagha } \\
\text { cavity }\end{array}$ & $\begin{array}{l}\text { Boring of genus Lithophaga in } \\
\text { limestone }\end{array}$ & MSL & $\begin{array}{l}\text { Living range: } \\
\text { MSL to } 25 \mathrm{~m} \\
\text { water depth }\end{array}$ & $\begin{array}{l}\text { Coletti et al., } \\
2020\end{array}$ \\
\hline $\begin{array}{l}\text { Cladocora } \\
\text { caespitosa reef }\end{array}$ & $\begin{array}{l}\text { Reef-like structure built by } \\
\text { coral colony }\end{array}$ & MSL & $\begin{array}{l}\text { Living range: } \\
5-20 \mathrm{~m} \text { water } \\
\text { depth }\end{array}$ & $\begin{array}{l}\text { Kruzic' and } \\
\text { Benkovic, } \\
(2008)\end{array}$ \\
\hline
\end{tabular}




\begin{tabular}{|c|c|c|c|c|}
\hline $\begin{array}{l}\text { Petaloconchus } \\
\text { vermid } \\
\text { construction }\end{array}$ & $\begin{array}{l}\text { Reef-like structure of sessile } \\
\text { marine gastropod often in } \\
\text { conjunction with encrusting } \\
\text { algae and other organisms }\end{array}$ & MSL & $\begin{array}{l}\text { Living range: } \\
1-50 \mathrm{~m} \text { water } \\
\text { depth }\end{array}$ & $\begin{array}{l}\text { Vescogni et } \\
\text { al. } 2008\end{array}$ \\
\hline
\end{tabular}

\section{$155 \quad 2.1$ Marine Terrace}

The marine terrace is a gently seaward dipping surface typically covered by a veneer of coastal sediment. It typically occurs on uplifting (and subsiding) coasts where the interaction between wave action, hard-rock lithology and sediment starvation allow a wave abrasion platform to form during sea-level highstand. Because the inner margin, located updip of the terrace deposit, is often buried by terrestrial sediments, reconstruction of the maximum shoreline position is a challenge and requires digital elevation model (DEM) analyses (e.g. Jara-Muñoz et al., 2016). In the eastern Mediterranean many of the marine terraces occur around the Aegean Sea as a result of ongoing deformation of the lithosphere at the Hellenic subduction zone (e.g., islands of Crete and Cyprus), along the North Anatolian transform fault (e.g., Marmara Sea), along the Kephalonia transform fault (southern Balkans) and along extensional faults (e.g. Gulf of Corinth, Antakya Graben). Because the terraces bear testimony to late Quaternary deformation history, they are often investigated in tectonic studies where dimension and elevation are constrained through DEM, DGPS and similar techniques and the timing of formation is deduced from radiometric dating of the terrace surface and deposits. Thus, as long as additional techniques (e.g., GPR) are not employed, the marine terrace is considered marine-limiting or it is a sea-level indicator with an uncertainty deduced from the DEM resolution (e.g., $5 \mathrm{~m})$.

\subsection{Coastal Notch}

170 Notches, typically carved in limestone cliffs, are a sea-level indicator formed by erosion. On the basis of form and shape they are differentiated in wave-cut notch and bio-erosional notch, both generated in the inter- to supratidal zone (Antonioli et al., 2015). Notches are regarded as accurate vertical markers of past sea level. When occurring on a micro-tidal coast, they are very precise because the vertical uncertainty is the tidal amplitude which is typically $15-30 \mathrm{~cm}$ in the eastern Mediterranean with the exception of the Gulf of Gabès (Tunisia) where the amplitude is around $70 \mathrm{~cm}$. To use the notch as a

175 sea-level indicator an unequivocally correlated and datable coastal deposit has to be available on site and this is rarely the case.

\subsection{Sediment Facies}

Eastern Mediterranean coastal sediments are represented by beach or fan-delta conglomerate, siliciclastic, carbonate and oolitic sand, clay and silt. These sediments may constitute beach ridges, barriers, veneers on terraces, beaches, lagoons or 
180 sabkhas resting in coastal onlap architecture on a flooding or erosional surface. A coastal deposit is undifferentiated and, hence, marine-limiting if the depositional environment has not been determined. It is considered a sea-level indicator where facies determination allows inferring water depth. The indicative range of each sediment facies vary depending on the coastal topography, rate of sediment supply and prevailing hydrodynamics and must be determined for each site separately. In general, the indicative range of foreshore deposits is 1-4 $\mathrm{m}$ and of shoreface deposits it is 4-8 $\mathrm{m}$ water depth. With the

185 small tidal range in the eastern Mediterranean the vertical precision of an index point deduced from sediment facies can be $<50 \mathrm{~cm}$ in places. However, with the difficulty of dating, the number of facies-based indicators remains small.

\subsection{Lithophagha Cavity}

The bivalve Lithophaga lithophaga belongs to the Mytilidae genera. Species of this genera are characterised by colonising hard substrates. They secret a calcium-binding substrate and thereby generate cavities that they inhabit (Coletti et al. 2020).

190 L. lithophaga live between the intertidal and $25 \mathrm{~m}$ water depth with highest abundance within $10 \mathrm{~m}$ water depth as reported for the Gulf of Naples (Coletti et al., 2020). The cavities are often observed on rock faces representing former cliffs and within the curvature of a notch suggesting that the bivalve colonises the cliff around mean sea level (Antonioli et al., 2015) with a relatively large uncertainty $(>5 \mathrm{~m})$, however, owing to the large living range of the bivalve (Lambeck et al., 2004).

\subsection{Cladocora Caespitosa Reef}

195 Cladocora caespitosa is a scleractinian polyp characterised by a corallite skeleton. It is a colonial coral species which forms banks of variable size on rocky and, occasionally, on sandy seabeds. The temperate coral is endemic to the Mediterranean where it shows relatively slow skeletal growth rates ranging from $1.3 \mathrm{~mm} \mathrm{yr}^{-1}$ (Peirano et al., 1999) to $6.2 \mathrm{~mm} \mathrm{yr}^{-1}$ (Kružic and Požar-Domac, 2003) mainly controlled by water temperature (Rodolfo-Metalpa et al., 2008). The colonies grow in shallow water and are rarely found below 30 m water depth (Kružić and Benkovic, 2008) and are therefore considered

200 marine-limiting. Living and fossil C. caespitosa colonies are reported for north and central Aegean Sea, Marmara Sea, Crete, Cyprus, Levant, Gulf of Gabès, north Tunisia and Strait of Sicily (Ozalp and Alparslan, 2011). The coral has been used predominantly for the purpose of U-series dating the associated LIG deposits with limited success, however, likely caused by the strong seawater temperature dependence (Trotter et al., 2011) and associated crystal instability of carbonate minerals compared to their tropical counterparts.

\section{$205 \quad 2.6$ Vermetidae Reef}

The vermetid reef is a biogenic dome- or reef-like structure dominated by sessile marine gastropods living in shallow water of warm-temperate seas (Vescogni et al., 2008). Two species are known: Petaloconchus dominating the vermetids reefs in the Neogene until the Pleistocene, replaced by Dendropoma in the Holocene (Laborel, 1986). Vermetid reefs grow in associations with coralline algae, bryozoans, serpulids and benthic foraminifera creating together a bioclastic calcarenite 210 (Bosellini et al., 2001). While the living range of Dendropoma is well-constrained from modern analogues to be the intertidal 
to upper subtidal zone (Laborel and Laborel-Deguen, 1994), the living range of Petaloconchus was reconstructed through facies analysis. These suggest beach down to the upper part of the slope (0-50 m; Vescogni et al., 2008) and, thus, Petaloconchus is considered marine-limiting.

\section{Elevation measurements}

215 Many of the studies listed above focused on stratigraphy, lithology or dating of the relevant coastal feature and did not emphasise elevation. Others, looking at the structural geology, reported elevation and associated measurement technique. Likewise, the sea-level datum was not reported to the detail desired for the WALIS database. In most cases "mean sea level" was used, also because the eastern Mediterranean tide is small and does not exceed $50 \mathrm{~cm}$ in most coastal zones. For the techniques used see Table 2 .

Table 2: Measurement techniques used to establish the elevation of MIS 5e shorelines.

\begin{tabular}{|c|c|c|}
\hline $\begin{array}{c}\text { Measurement } \\
\text { technique }\end{array}$ & Description & Typical precision \\
\hline TK Proflex 500 GPS & & $\begin{array}{c}0.02 \mathrm{~m} \text { to } 0.08 \mathrm{~m} \text { (Rovere et al., } \\
2016)\end{array}$ \\
\hline $\begin{array}{c}\text { Hand-held barometric } \\
\text { altimeter }\end{array}$ & $\begin{array}{c}\text { Difference in barometric pressure between a } \\
\text { point of known elevation and a point of } \\
\text { unknown elevation }\end{array}$ & Not reported \\
\hline $\begin{array}{c}\text { Topographic map } \\
\text { Cape measure }\end{array}$ & Manually rolled tape measure and hand level & $>10 \mathrm{~m}$ \\
\hline
\end{tabular}

\section{Eastern Mediterranean RSL sites}

In total 21 indicators are listed in the two databases and displayed against their longitudinal position in Fig. 6. When taking 225 the uncertainty into account, the minimum and maximum LIG sea level is at $-5.1 \mathrm{~m}$ and $23 \mathrm{~m}$, respectively. All facies-based indicators are characterised by small indicative ranges, but some are associated with large uncertainties owing to poorly constrained elevation data. From the 21 indicators displayed in Fig. 6 we describe here the 12 most reliable ones with their WALIS ID. These are situated on coastal zones affected by the interplay of eustacy and associated regional GIA only and 
provide age constraints and/or the Senegal fauna. Zones with minor or debated non-GIA contributions are also included.

230 Coastal zones for which non-GIA processes during the late Quaternary are unambiguously evident are excluded (for zones see Fig. 1). For the selected zones we assume coastal geometries, hence tidal prism, to be similar to today because the course of the LIG beach ridges and barriers suggest a LIG coastline running sub-parallel to the modern one. The mean tidal range today is $0.5 \mathrm{~m}$ (Admiralty Tide tables) apart from the Gulf of Gabès (1.5 m; Gzam et al., 2016).

\subsection{Black Sea rift zone}

235 Sile (ID 927; Fig. 1) - the around $80 \mathrm{~cm}$ thick cemented, moderately sorted bioclast-rich sand (“Coquinite”; Erginal et al. 2017) shows seaward dipping laminae in its lower part and tabular planar cross-beds in its upper part; depositional environment is foreshore to beach (Erginal et al., 2017). The deposit is situated at $0 \pm 1 \mathrm{~m}$. Assuming a virtual absence of tides in the Black Sea (Medvedev et al., 2016) and an operational Bosporus gateway during LIG, this is a facies-based sea-level indicator with an indicative range of 0-2 $\mathrm{m}$ water depth. The palaeo-sea level is at $0.0 \pm 1.5 \mathrm{~m}$ at $127 \pm 9 \mathrm{ka}$ (Erginal et al., 240 2017). The site is affected by subsidence estimated to $\sim 2.3 \mathrm{~mm} / \mathrm{a}$ (Avsar et al., 2017).

\subsection{Nile littoral cell zone}

Nahel Me'arot (ID 942; Fig. 2) - the around 5 m thick cemented oolitic grainstone shows seaward dipping planar laminae and the depositional environment is lower foreshore to upper shoreface deduced from modern analogue (Mauz et al., 2012). The elevation is 3-6 m (Galili et al., 2007). This is a facies-based sea-level indicator with an indicative range of 3-6 m water 245 depth. The palaeo-sea level is at $7 \pm 2 \mathrm{~m}$ at $113 \pm 5 \mathrm{ka}$. 


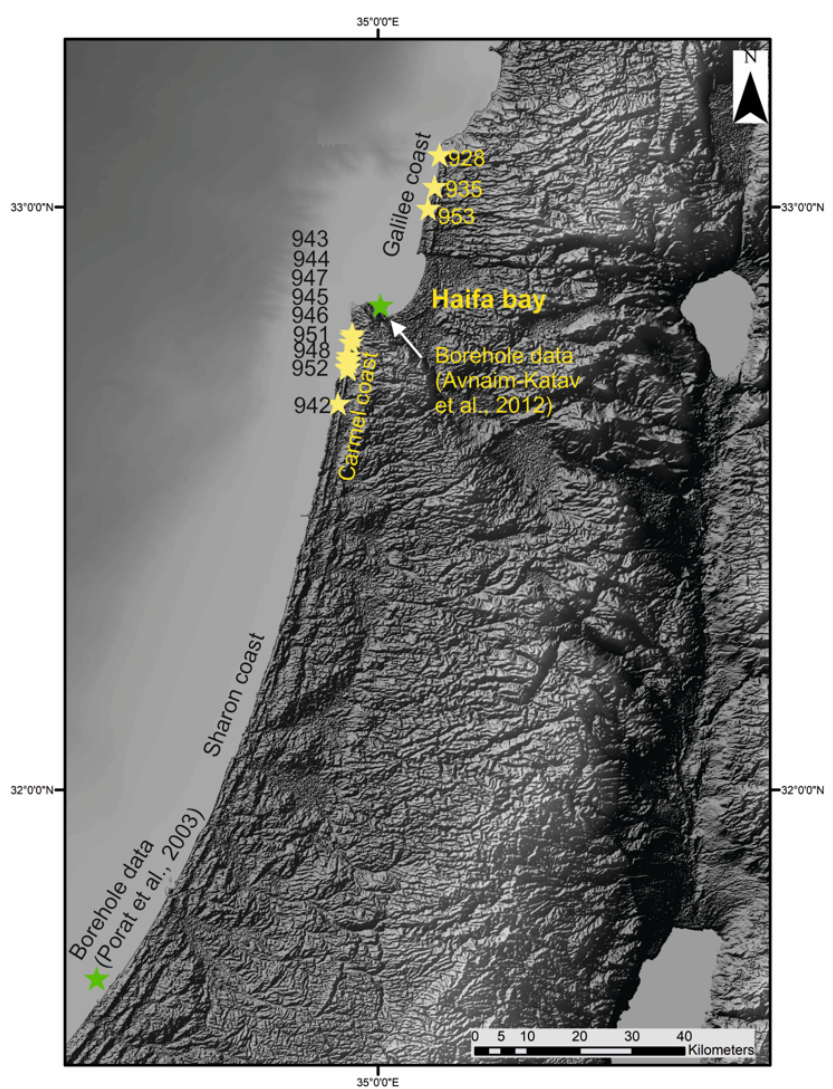

Fig. 2. The Levant Sea coast of Israel. Local names for the coast are Galilee, Carmel and Sharon for the northern, central and southern coast, respectively. Datapoints included in the WALIS database are depicted with their WALIS ID (e.g. 945). Green stars indicate location of borehole. Gebco data were obtained from GEBCO Compilation Group (2020) GEBCO 2020

250 Grid (doi:10.5285/a29c5465-b138-234d-e053-6c86abc040b9). SRTM data were obtained from http://srtm.csi.cgiar.org (Jarvis et al., 2008).

\subsection{African passive continental margin zone}

El-Max-Abu Sir (ID 1362; Fig. 3) - The LIG shoreline is represented by the second beach ridge behind the modern coastline. Cross-bedded bioclastic and oolitic grainstone of foreshore depositional environment (Elshazly et al., 2019) constitute the 255 basal part of the ridge. The elevation should be $<5 \mathrm{~m}$ but is poorly defined. This is a facies-based sea-level indicator with an indicative range of 1-3 m water depth. The palaeo-sea level is at $0.5 \pm 4.6 \mathrm{~m}$ at $121 \pm 6 \mathrm{ka}$ (El-Asmar, 1994). 


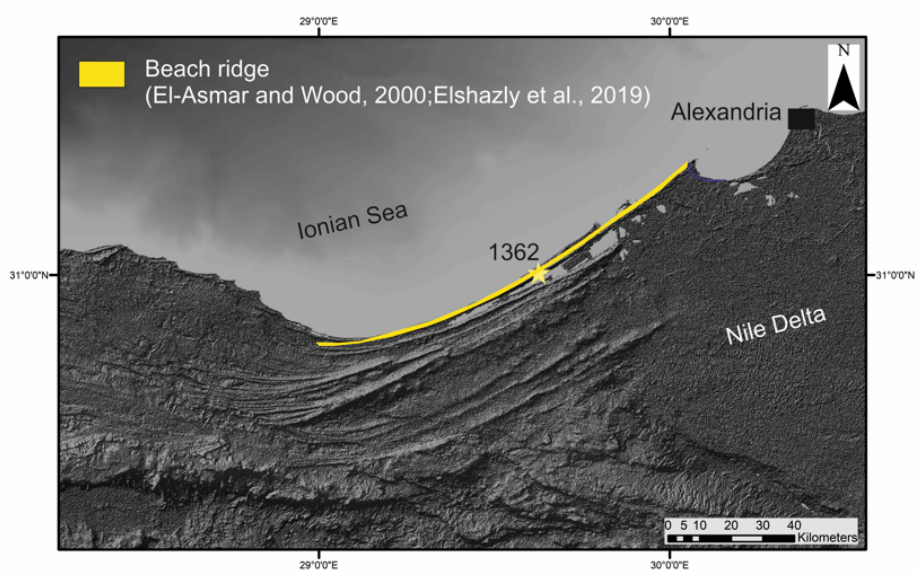

Fig. 3. The Ionian Sea coast west of the Nile delta (Egypt). The WALIS datapoint is ID 1362. Gebco data were obtained from GEBCO Compilation Group (2020) GEBCO 2020 Grid (doi:10.5285/a29c5465-b138-234d-e053-6c86abc040b9).

260 SRTM data were obtained from http://srtm.csi.cgiar.org (Jarvis et al., 2008).

Ras Karboub (ID 1363; Fig. 4) - This site is part of the Jeffara barrier stretching almost parallel to the modern coastline from Sabratah (Libya) to Djerba island (Tunisia). The barrier shows siliciclastic sand of shoreface to foreshore gradually passing into oolitic grainstone of foreshore environment (Jedoui et al., 2003; Mauz et al., 2009). The elevation should be 5-10 m but 265 is poorly defined. This is a facies-based sea-level indicator with an indicative range of $+1 \mathrm{~m}$ to $-3 \mathrm{~m}$. The palaeo-sea level is at $7 \pm 10 \mathrm{~m}$ at $114 \pm 16 \mathrm{ka}$ (Mauz et al., 2012).

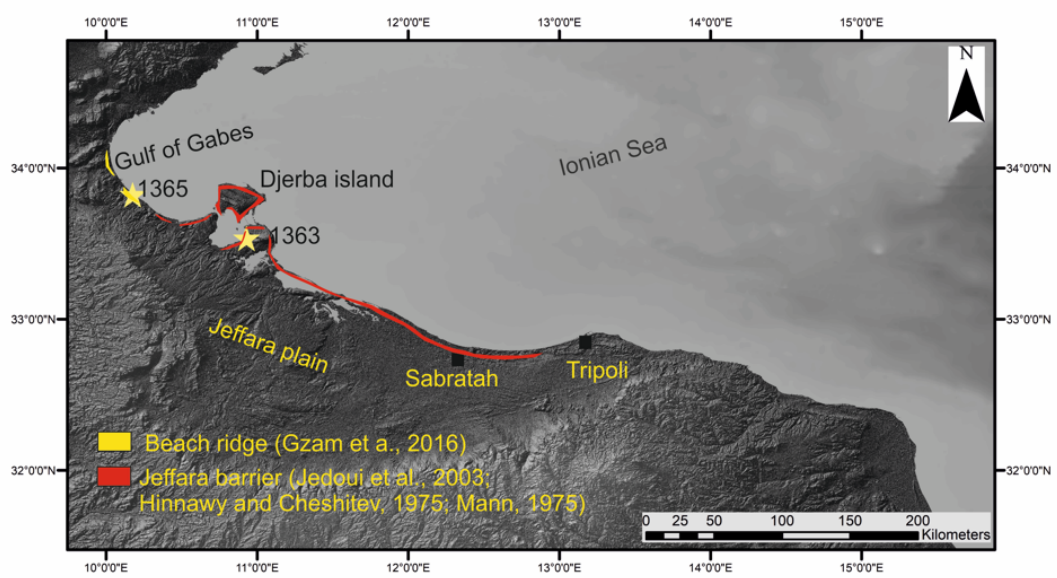

Fig. 4. The Ionian Sea coast between the Gulf of Sirte and the Gulf of Gabès (Libya and Tunisia) The datapoints included in the WALIS database are depicted with their WALIS ID. Gebco data were obtained from GEBCO Compilation Group (2020) 
270 GEBCO 2020 Grid (doi:10.5285/a29c5465-b138-234d-e053-6c86abc040b9). SRTM data were obtained from http://srtm.csi.cgiar.org (Jarvis et al., 2008).

Khniss (ID 1364; Fig. 5) - This site is part of the Hammamet barrier stretching almost parallel to the modern coastline from Chebba to ID 926. The barrier shows siliciclastic sand of shoreface to foreshore environment gradually passing into oolitic 275 grainstone of foreshore environment (Jedoui et al., 2003; Mauz et al., 2009). The elevation should be 5-10 m but is poorly defined. This is a facies-based sea-level indicator with an indicative range of $+1 \mathrm{~m}$ to $-3 \mathrm{~m}$. The palaeo-sea level is at $10 \pm 3 \mathrm{~m}$ at $121 \pm 10 \mathrm{ka}$ (Mauz et al., 2009).

Hergla (ID 926; Fig. 5) - the around $2 \mathrm{~m}$ thick cemented bioclastic quartz sand shows planar laminae; the depositional environment is foreshore (Mauz et al., 2018). The elevation of the corresponding shoreline should be at 3-2 m deduced from

280 the altitude of the coeval lagoonal deposit (Mauz et al., 2018). This is a facies-based sea-level indicator with an indicative range of 1-3 m water depth. The palaeo-sea level is at $4.2 \pm 1.8 \mathrm{~m}$ at $120 \pm 5 \mathrm{ka}$.

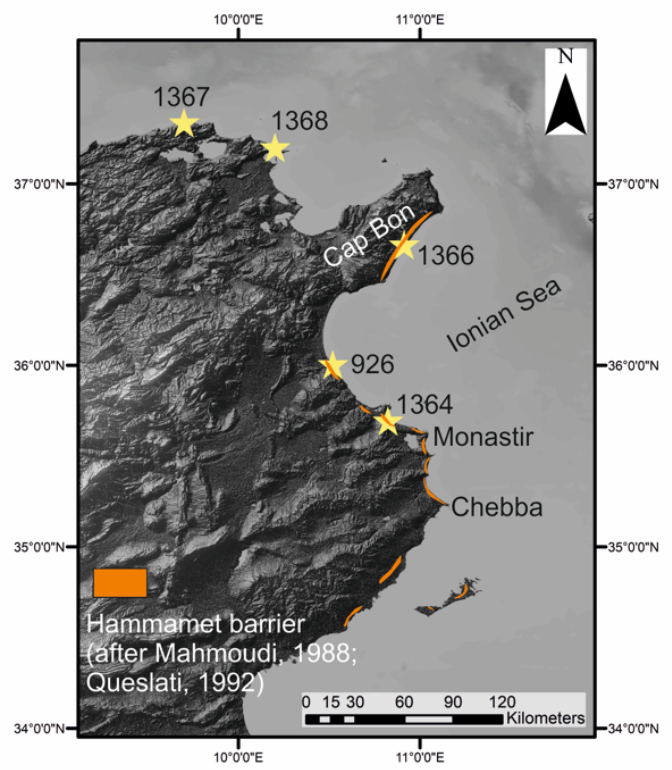

Fig. 5. The westernmost Ionian Sea coast (Tunisia). The datapoints included in the WALIS database are depicted with their WALIS ID. Gebco data were obtained from GEBCO Compilation Group (2020) GEBCO 2020 Grid (doi:10.5285/a29c5465-

b138-234d-e053-6c86abc040b9). SRTM data were obtained from http://srtm.csi.cgiar.org (Jarvis et al., 2008).

\subsection{Coastal lowlands}

Rosh Hanikra (ID 928) and Shavey Zion (ID 935; Fig. 2) - in both sites the Strombus bubonius-bearing deposit is a poorly sorted bioclast bearing conglomerate resting on the surface of an abrasion platform (marine terrace); depositional 
environment is the swash zone of the beach (Sivan et al., 2016). The deposit is situated at $1.3-2.4 \mathrm{~m}$ (Sivan et al., 2016).

290 This is a facies-based sea-level indicator with an indicative range that includes storm wave swash height and breaking depth. The palaeo-sea level is at $1.8 \pm 1.0 \mathrm{~m}$ (average of $n=3$ indicators and standard deviation) during MIS 5e.

Gulf of Gabès (ID 1365; Fig. 4) - The LIG deposit is part of a coastline-parallel beach ridge. The lower part of the ridge is characterised by planar laminated beds of bioclastic sand bearing Strombus bubonius fossil remains (Gzam et al., 2016). The deposit is situated at $3 \mathrm{~m}$ (Gzam et al., 2016). This is a facies-based sea-level indicator with an indicative range of $+3 \mathrm{~m}$ to 0 $295 \mathrm{~m}$ including $1.5 \mathrm{~m}$ mean tidal range. The palaeo-sea level is at $1.5 \pm 3.4 \mathrm{~m}$ during MIS $5 \mathrm{e}$.

\subsection{Alpine orogenic belt}

Korba (ID 1366; Fig 5) - This site is part of the Cap Bon barrier stretching almost parallel to the modern coastline (Elmejdoub and Jedoui 2009). The barrier shows siliciclastic sand in cross-bed or foreset bedding bearing Strombus bubonius in places (Elmejdoub and Jedoui 2009). The depositional environment is foreshore to beach (Elmejdoub and 300 Jedoui, 2009; Mauz et al., 2012). The elevation should be 5-10 m but is poorly defined. This is a facies-based sea-level indicator with an indicative range of $+1 \mathrm{~m}$ to $-3 \mathrm{~m}$. The palaeo-sea level is at $13 \pm 10 \mathrm{~m}$ during MIS $5 \mathrm{e}$.

Rass Zebib (ID 1368; Fig. 5) - the indicator is part of a cliff section the lower part of which is characterised by planar laminated beds of bio- and siliciclastic sand of shoreface to foreshore environment (Mauz et al., 2009). The elevation should be around $5 \mathrm{~m}$ but is poorly defined. This is a facies-based sea-level indicator with an indicative range of $-3 \mathrm{~m}$ to $-8 \mathrm{~m}$. The 305 palaeo-sea level is at $11 \pm 6 \mathrm{~m}$ at $131 \pm 7 \mathrm{ka}$ (Mauz et al., 2009).

Ras el Korane (ID 1367; Fig. 5) - the indicator is part of a cliff section the middle part of which is characterised by lowangle cross bedded bioclastic calcarenites (Wided et al., 2019). The depositional environment is foreshore. The elevation should be 5-6 $\mathrm{m}$ but is poorly defined. This is a facies-based sea-level indicator with an indicative range of $-1 \mathrm{~m}$ to $-5 \mathrm{~m}$. The palaeo-sea level is at $8 \pm 5 \mathrm{~m}$ during MIS 5e as deduced from facies correlation (Wided et al., 2019). 


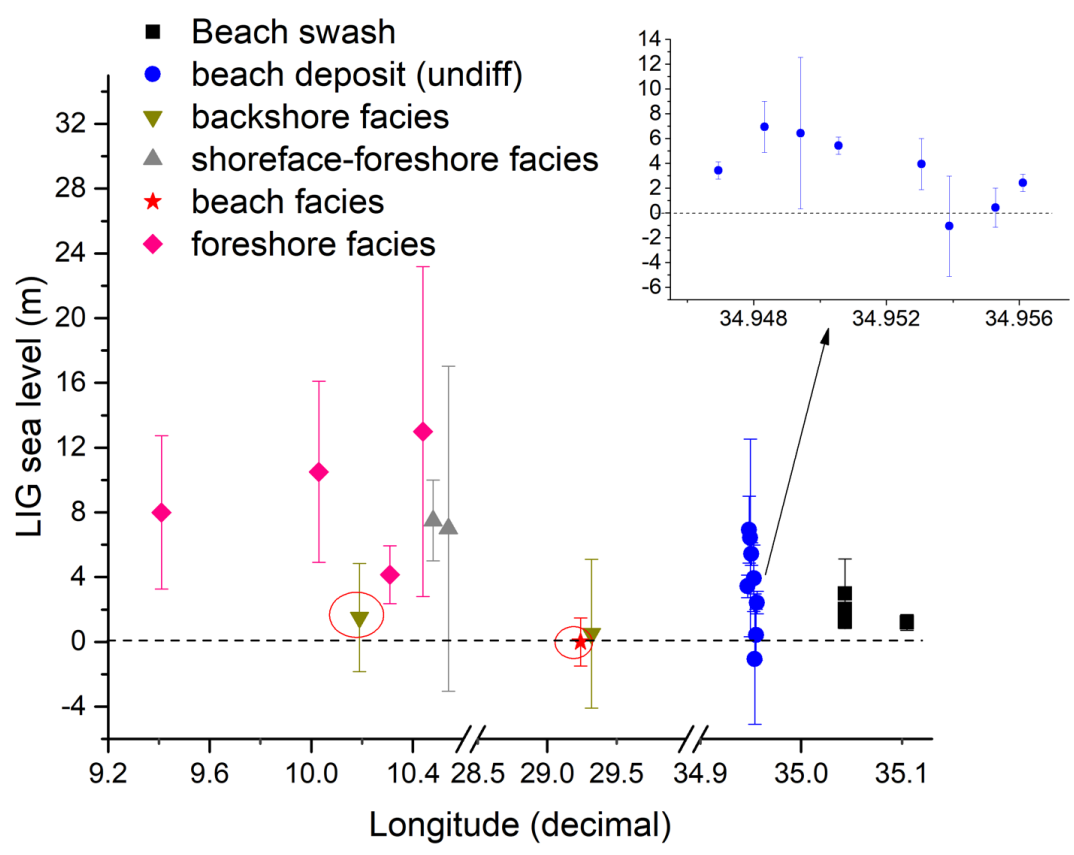

Fig. 6. The eastern Mediterranean sea-level indicators plotted against their longitudinal position. Red circle highlights datapoints potentially affected by non-GIA processes. The inset displays the sites on Carmel coast (Israel; Galili et al., 2007).

\section{Further details}

\section{$315 \quad 5.1$ Impact of GIA mechanisms on LIG shoreline elevation}

Similar to other mid-latitudinal coastal areas (e.g., US-Carolina coast; Parham et al., 2007) controversies exist on the position of the MIS 5 shorelines. In fact, in none of the tectonically dormant coastal zones reviewed here the LIG shoreline is observed at the commonly expected $6 \mathrm{~m}$ altitude (Fig. 6). Furthermore, for the MIS 5a Dorale et al. (2010) indicate that the shoreline in the West Mediterranean should have been close to modern MSL, but at Hergla (ID 926) the shoreline is at $\sim 4 \mathrm{~m}$ (Mauz et al., 2018). Following results from geophysical modelling (e.g., Creveling et al., 2015) even the far-field shoreline can depart by up to $4 \mathrm{~m}$ from the eustatic value owing to local dynamic topography (e.g., Austermann et al., 2017). On the other hand, the LIG eustatic level is reconstructed probabilistically with a $4 \mathrm{~m}$ uncertainty (Kopp et al., 2013). Transferring these findings to the eastern Mediterranean, we can say that on tectonically dormant coasts the LIG sea level must have been situated at $5 \pm 8 \mathrm{~m}$. In fact, most of our datapoints depicted in Fig. 6 fall in this range of $-3 \mathrm{~m}$ to $13 \mathrm{~m}$. 


\subsection{Last Interglacial sea-level fluctuations}

Sea-level fluctuation within LIG is reported from two sites: one site is Rosh Hanikra (ID 928) where the sea level fell from $3.3 \mathrm{~m}$ to $0.8 \mathrm{~m}$ and rose again to $6.5 \mathrm{~m}$ (Sivan et al., 2016). The other site is Hergla (ID 926) where the sea level should have risen first to $3 \mathrm{~m}$, then dropped to near or below MSL and rose again to $4 \mathrm{~m}$ (Hearty et al. 2007). For this latter site, however, Mauz et al (2018) showed that the upper marine deposit at $4 \mathrm{~m}$ is younger than LIG.

\section{Future research directions}

With regard to LIG sea-level research the most interesting sites are situated on the African passive continental margin where tectonic movements are minimal and sediment supply is sufficient to generate a datable sea-level indicator with a small vertical uncertainty. Coastal zones that merit further attention are (1) the Carmel coast (Israel), where the LIG highstand

335 formed a sediment wedge in onlap architecture (Fig. 2), and (2) the north Africa coast where LIG sediments formed a large barrier preserved in patches (Figs 4 and 5). In addition, the datapoints depicted in Fig. 6 that do not fall in the predicted range of $5 \pm 8 \mathrm{~m}$ LIG sea-level elevation deserve further analysis.

\section{Data availability}

The two databases are available open access and are kept updated as necessary at the following links:

http://doi.org/10.5281/zenodo.4274178 (Sivan and Galili, 2020) and http://doi.org/10.5281/zenodo.4283819 (Mauz, 2020). The files at these links were exported from the WALIS database interface on 15 November 2020 and on 21 November 2020, respectively. Description of each data field in the database is contained at this link: https://doi.org/10.5281/zenodo.3961543 (Rovere et al., 2020), that is readily accessible and searchable here: https://walishelp.readthedocs.io/en/latest/. More information on the World Atlas of Last Interglacial Shorelines can be found here: https://warmcoasts.eu/world-atlas.html. Users of our database are encouraged to cite the original sources in 345 addition to our database and this article.

\section{Author contribution}

B.M. was primary author and responsible for writing of the text and design of the figures, including all entries into WALIS regarding the eastern Mediterranean (except Israel). D.S. and E.G. compiled the data for the Israel coast and are responsible for relevant entries into WALIS.

\section{Competing interests}

The authors declare that they have no conflict of interest.

\section{Acknowledgements}

We thank Lotem Robins (Haifa) for uploading the Israel data to the WALIS database, Sara Stuecker (Salzburg) for generating the DEMs used for the map-based figures and Noureddine Elmejdoub (Gabès) for compiling the Tunisia data.

355 The data described in this paper were compiled in WALIS, a sea-level database interface developed by the ERC Starting Grant "WARMCOASTS" (ERC-StG-802414), in collaboration with PALSEA (PAGES / INQUA) working group. The database structure was 
designed by A. Rovere, D. Ryan, T. Lorscheid, A. Dutton, P. Chutcharavan, D. Brill, N. Jankowski, D. Mueller, M. Bartz, E. Gowan and K. Cohen.

\section{References}

Admiralty Tide tables, available at https://www.admiralty.co.uk/digital-services/catalogues/admiralty-digital-catalogue.

Antonioli, F., Lo Presti, V., Rovere, A., Ferranti, L., Anzidei, M., Furlani, S., Mastronuzzi, G., Orru, P.E., Scicchitano, G., Sannino, G., Spaminato, C.R., Pagliarulo, R., Deiana, G., de Sabata, E., Sanso, P., Vacchi, M. and Vecchio, A.: Tidal notches in Mediterranean Sea: a comprehensive analysis. Quat. Sci. Rev., 119, 66-84, http://dx.doi.org/10.1016/j.quascirev.2015.03.016, 2015.

Armijo, R., Meyer, B., King, G. C. P., Rigo, A., D. Papanatassiou, D.: Quaternary evolution of the Corinth Rift and its implications for the Late Cenozoic evolution of the Aegean. Geophys. J. Int. 126, 11-53, 1996.

Athanassis, C., Foutoulis, I.: Quaternary Neotectonic Configuration of the Southwestern Peloponnese, Greece, Based on Luminescence Ages of Marine Terraces. Journal of Earth Science, 24, No. 3, 410-427, DOI: 10.1007/s12583-013-0334-1, 3702013.

Austermann, J., Jerry X. Mitrovica, Huybers, P. and Rovere, A.: Detection of a dynamic topography signal in last interglacial sea-level records. Science Advances 2017:3, e1700457, 2017.

Avnaim-Katav, S., Almogi-Labin, A., Sandler, A., Sivan, D., Porat, N. and Matmon, A.: The chronostratigraphy of a Quaternary sequence at the distal part of the Nile littoral cell, Haifa Bay, Israel. J. Quat. Sci. 27(7), 675-686, DOI:

$37510.1002 /$ jqs.2537, 2012.

Avsar, N.B., Shuanggen Jin, S. Hakan Kutoglu, Gurbuz, G.: Vertical land motion along the Black Sea coast from satellite altimetry, tide gauges and GPS. Advances in Space Research 60, 2871-2881, http://dx.doi.org/10.1016/j.asr.2017.08.012, 2017.

Bialik, O.M., Frank, M., Betzler, C., Zammit, R. and Waldmann, N.D.: Two-step closure of the Miocene Indian Ocean Gateway to the Mediterranean. Sci. Reports 9:8842, https://doi.org/10.1038/s41598-019-45308-7, 2019.

Brew, G. Barazangi, M., Al-Maleh, A.K. and Sawaf, T.: Tectonic and Geologic Evolution of Syria. GeoArabia, 6, No. 4, 573-615, 2001.

Bulkan, S., Vannucchi, P., Gasperini, L., Polonia, A and Cavozzi, C.: Modelling tectonic deformation along the NorthAnatolian Fault in the Sea of Marmara. Tectonophysics 794, 228612, https://doi.org/10.1016/j.tecto.2020.228612, 2020.

385 Coletti, A., Savinelli, B., Di Muzio, G., Rizzo, L., Tamburello, L. Fraschetti, S. Musco, L., Danovaro, R.: The date mussel Lithophaga lithophaga: Biology, ecology and the multiple impacts of its illegal fishery. Science of the Total Environment 744, 140866, https://doi.org/10.1016/j.scitotenv.2020.140866, 2020.

Collier, R.E.LL.: Eustatic and tectonic controls upon Quaternary coastal sedimentation in the Corinth Basin, Greece. Journal of the Geological Society, London, 147, 301-314, 1990.

390 Creveling, J., Jerry X. Mitrovica, Carling C. Hay, Jacqueline Austermann, Robert E. Kopp: Revisiting tectonic corrections applied to Pleistocene sea-level highstands. Quat. Sci. Rev. 111, 72-80, http://dx.doi.org/10.1016/j.quascirev.2015.01.003, 2015.

Davis, M., Matmon, A., Root, D.H. and Avnaim-Katav, S.: Constant cosmogenic nuclide concentrations in sand supplied from the Nile River over the past 2.5 m.y. Geology, doi:10.1130/G32574.1, 2012. 
De Gelder, G., Fernández-Blanco, D., Melnick, D., Duclaux, G., Bell, R.E., Jara-Muñoz, J., Armijo, R., Lacassin, R.: Lithospheric flexure and rheology determined by climate cycle markers in the Corinth Rift. Sci. Reports, https://doi.org/10.1038/s41598-018-36377-1, 2019.

Dodonov, A. E., Trifonov, V. G., Ivanova, T. P., Kuznetsov, V. Y., Maksimov, F. E., Bachmanov, D. M., Sadchikova, A.N., Minini, H., Al-Kafri, A.-M. and Ali, O.: Late Quaternary marine terraces in the Mediterranean coastal area of Syria: Geochronology and neotectonics. Quat. Int. 190(1), 158-170, doi:10.1016/j.quaint.2008.02.008, 2008.

Dorale, J.A., Onac, B.P., Fornos, J.J., Gines, J., Gines, A., Tuccimei, P., Peate, D.W.: Sea-level highstand 81,000 years ago in Mallorca. Science 327, 860-863, 10.1126/science.1181725, 2010.

El-Asmar, H.M.: Aeolianite sedimentation along the northwestern coast of Egypt: Evidence for middle to late Quaternary aridity. Quaternary Science Reviews 13, 699-708, 1994.

405 El-Asmar, H.M., and Wood, P.: Quaternary shoreline development: the northwestern coast of Egypt: Quaternary Science Reviews 19, 1137-1149, 2000.

Elmejdoub, N. and Jedoui, Y.: Pleistocene raised marine deposits of the Cap Bon peninsula (N-E Tunisia): Records of sealevel highstands, climatic changes and coastal uplift. Geomorphology 112, 179-189, doi:10.1016/j.geomorph.2009.06.001, 2009.

410 Elshazly, A., El-Sayed, M.K. and Pascucci, V.: A sedimentary depositional and diagenetic model of a Pleistocene/Holocene coastal formation in Alexandria, Mediterranean Sea, Egypt. J. Afr. Earth Sci. 158, 103552, https://doi.org/10.1016/j.jafrearsci.2019.103552, 2019.

Emery, K.O., Neev, D.: Mediterranean beaches of Israel. Bulletin Geological Survey Israel 26, 1-23, 1960.

Erginal, A.E., Nafiye Güne. Kıyak, Hamit Haluk Selim, Mustafa Bozcu, Muhammed Zeynel .ztürk, Yunus Levent Ekinci, Alper Demirci, Elmas Kırcı Elmas, Tug ba .ztürk, Çag`lar Çakır, Mustafa Karabıyıkog `lu: Eolianite and coquinite as evidence of MIS 6 and 5, NW Black Sea coast, Turkey. Aeolian Research 25, 1-9, http://dx.doi.org/10.1016/j.aeolia.2017.01.004, 2017.

Galili, E., Zviely, D., Ronen, A., Mienis, H.K.: Beach deposits of MIS 5e high sea stand as indicators for tectonic stability of the Carmel coastal plain. Israel. Quaternary Science Review, 26, 2544-2557, 2007.

420 Galili, E., Sevketoglu, M., Salamon, A., Zviely, D., Mienis, H.K., Rosen, B. and Moshkovitz, S.: Late Quaternary beach deposits and archaeological relicts on the coasts of Cyprus, and the possible implications of sea-level changes and tectonics on the early populations, in: Geology and Archaeology: Submerged Landscapes of the Continental Shelf, edited by: Harff, J., Bailey, G. and Luth, F., Geological Society, London, Special Publications, 411, 179-218, http://dx.doi.org/10.1144/SP411.10, 2016.

425 Galili, E., Ronen, A., Mienis, H.K. and Horwitz, L.K.: Beach deposits containing middle Paleolithic archaeological remains from northern Israel. Quat. Int. 464, 43-57, http://dx.doi.org/10.1016/j.quaint.2017.05.002, 2018.

Gallen, S.F., K.W. Wegmann, D.R. Bohnenstiehl, F.J. Pazzaglia, M.T. Brandon, C. Fassoulas: Active simultaneous uplift and margin-normal extension in a forearc high, Crete, Greece. Earth Plan. Sci. Lett. 398, 11-24, http://dx.doi.org/10.1016/j.eps1.2014.04.0380012-821X, 2014.

430 Gawthorpe, R.L., Leeder, M.R., Kranis, H., Skourtsos, E., Andrews, J.E., Gijs A. Henstra, Greg H. Mack, Martin Muravchik, Jenni A. Turner, Michael Stamatakis: Tectono-sedimentary evolution of the Plio-Pleistocene Corinth rift, Greece. Basin Research 30, 448-479, doi: 10.1111/bre.12260, 2018.

Gibbard, P., Cohen, K.: Global chronostratigraphical correlation table for the last 2.7 million years. Episodes 31, 243-247, 2008. 
435 Giglia, G.: Explanatory Booklet, Sheet: Ajdabiya, NH 34-6. Geological map of Libya. Industrial research Centre Tarabulus, Centro Ricerche Geologiche S.p.A., Firence, Italy, p. 1-93, 1984.

Gignoux, M... Les formations marines Pliocènes et Quaternaires de l'Italie du sud et de la Sicile. Ann. d. L'Univ.Lyon N. S., 36, 1913.

Granot, R.: Palaeozoic oceanic crust preserved beneath the eastern Mediterranean. Nat. Geosci., DOI: 10.1038/NGEO2784, 2016.

Gzam, M., Elmejdoub, N. and Jedoui, Y.: Late Quaternary sea level changes of Gabes coastal plain and shelf: Identification of the MIS 5c and MIS 5a onshore highstands, southern Mediterranean. J. Earth Syst. Sci. 125, No 1, 13-28, 2016.

Hafkenscheid, E., Wortel, M.J.R. and Spakman, W.: Subduction history of the Tethyan region derived from seismic tomography and tectonic reconstructions. J. Geophys. Res. 111, B08401, doi:10.1029/2005JB003791, 2006.

445 Hearty, P.J.: An inventory of last interglazial (sensu lato) age deposits from the Mediterranean basin: a study of isoleucine epimerisation and U-Series dating. Zeitschrift fur Geomorphologie, Supplementum 62, 51-69, 1986.

Hearty, P.J., Hollin, J.T., Neumann, A.C., O’Leary, M.J., McCulloch, M.: Global sea- level fluctuations during the Last Interglaciation (MIS 5e). Quaternary Science Reviews 26, 2090-2112, 2007.

El-Hinnawy, M. and Cheshitev, G.: Explanatory Booklet, Sheet: Tarabulus, NI 33-13. Geological map of Libya. Libyan Arab Republic, Industrial research Centre, p. 1-55, 1975.

Issar, A., and Kafri, U.: Neogene and Pleistocene geology of the Western Galilee coastal plain, Geological Survey of Israel Bulletin 53, 1-14, 1972.

Jara- Muñoz, J., Melnick, D., Strecker, M.R.: TerraceM: A MATLAB ${ }^{\circledR}$ tool to analyze marine and lacustrine terraces using high-resolution topography. Geosphere 12(1), 176-195, doi:10.1130/GES01208.1, 2016.

Jarvis, A., H.I. Reuter, A. Nelson, E. Guevara,: Hole-filled SRTM for the globe Version 4, available from the CGIAR-CSI SRTM 90m Database http://srtm.csi.cgiar.org, 2008

Jedoui, Y., Reyss, J.-L., Kallel, N., Montacer, M., Ismaïl, H.B., Davaud, E.: U-series evidence for two high Last Interglacial sea levels in southeastern Tunisia. Quaternary Science Reviews 22, 343-351 2003.

Jenkins, J., Stephenson, S.N., Martinez-Garzon, P., Bohnhoff, M. and Nurlu, M.: Crustal Thickness Variation Across the Sea of Marmara Region, NW Turkey: A Reflection of Modern and Ancient Tectonic Processes. Tectonics 39, e2019TC005986. https://doi.org/10.1029/2019TC005986, 2020.

Keraudren, B., Sorel, D.: The terraces of Corinth (Greece) A detailed record of eustatic sea-level variations during the last 500,000 years. Mar. Geol. 77, 99-107, 1987.

Kopp, R.E., Simons, F.J., Mitrovica, J.X., Maloof, A.C. and Oppenheimer, M.: Probabilistic assessment of sea level during the last interglacial stage. Nature 462, 863-868, doi:10.1038/nature08686, 2009.

Kopp, R.E., Frederik J. Simons, Jerry X. Mitrovica, Adam C. Maloof, Michael Oppenheimer: A probabilistic assessment of sea level variations within the last interglacial stage. Geophys. J. Int. 193, 711-716, doi: 10.1093/gji/ggt029, 2013.

Kružic, P., Benkovic, L.: Bioconstructional features of the coral Cladocora caespitose (Anthozoa, Scleractinia) in the Adriatic Sea (Croatia). Marine Ecology 29, 125-139, doi:10.1111/j.1439-0485.2008.00220.x, 2008.

470 Kružic, P., Požar-Domac, A.: Banks of the coral Cladocora caespitose (Anthozoa, Scleractinia) in the Adriatic Sea. Coral Reef 22, 536, DOI 10.1007/s00338-003-0345-y, 2003. 
Laborel, J.: Vermetids, in: Van de Plassche, O. (ed), Sea-level research, a manual for the collection and evaluation of data. Norwich: Geo Books, 1986.

Laborel, J., Laborel-Deguen, F.: Biological indicators of relative sea-level variations and of co-seismic displacements in the Mediterranean region. J. Coast. Res. 10 (2), 395-415, 1994.

Lambeck, K., Antonioli, F., Purcell, A., Silenzi, S.: Sea-level change along the Italian coast for the past 10,000 yr. Quat. Sci. Rev. 23, 1567-1598, doi:10.1016/j.quascirev.2004.02.009, 2004.

Mahmoudi, M.: Nouvelle proposition de subdivisions stratigraphiques des depots attribues au Tyrrhenien en Tunesie (region de Monastir). Bull. Soc. Geol. France 8(3), 431-435., 1988.

480 Mann, K.: Explanatory Booklet, Sheet: Al Khums, NI 33-14. Geological map of Libya. Libyan Arab Republic, Industrial research Centre Tripoli, p. 1-80, 1975.

Mauz, B., Fanelli, F, Elmejdoub, N. and Barbieri, R.: Coastal response to climate change: Mediterranean shorelines during the last interglacial (MIS 5). Quaternary Science Reviews 54, 89-98, doi:10.1016/j.quascirev.2012.02.021, 2012.

Mauz, B., Shen, Z., Elmejdoub, N. and Spada, G.: No evidence from the eastern Mediterranean for an MIS 5e double peak sea-level highstand. Quaternary Research, 1-6 doi:10.1017/qua.2017.111, 2018.

Mauz, B.: Database of last interglacial sea-level proxies in the eastern Mediterranean. Zenodo. http://doi.org/10.5281/zenodo.4283819, 2020.

McNeill, L.C., Donna J. Shillington, Gareth D. O. Carter, Jeremy D. Everest, Robert L. Gawthorpe, Clint Miller, Marcie P. Phillips, Richard E., Ll. Collier, Aleksandra Cvetkoska, Gino De Gelder, Paula Diz, Mai-Linh Doan, Mary Ford, Maria

490 Geraga, Jack Gillespie, Romain Hemelsdaël, Emilio Herrero-Bervera, Mohammad Ismaiel, Liliane Janikian, Katerina Kouli, Erwan Le Ber, Shunli Li, Marco Maffione, Carol Mahoney, Malka L. Machlus Georgios Michas, Casey W. Nixon, Sabire Asli Oflaz, Abah P . Omale, Kostas Panagiotopoulos, Sofia Pechlivanidou, Simone Sauer, Joana Seguin, Spyros Sergiou, Natalia V. Zakharova, Sophie Green: High-resolution record reveals climate-driven environmental and sedimentary changes in an active rift. Scientific Reports, https://doi.org/10.1038/s41598-019-40022-w, 2018.

McPhee, P., van Hinsbergen, D.J.J.: Tectonic reconstruction of Cyprus reveals Late Miocene continental collision of Africa and Anatolia. Gondwana Research 68, 158-173, https://doi.org/10.1016/j.gr.2018.10.015, 2019.

Medvedev, I.P., Rabinovich, A.B. and Kullkov, E.A.: Tides in three enclosed basins: The Baltic, Black, and Caspian Seas. Front. Mar. Sci. 3:46. doi: 10.3389/fmars.2016.00046, 2016.

Miall, A.D.: The geology of stratigraphic sequences. Springer-Verlag Berlin Heidelberg, DOI: 10.1007/978-3-642-05027-5, 2010.

Morhange, C., Pirazzoli, P.A., Marriner, N., Montaggioni, L.F. and Nammour, T.: Late Holocene sea-level changes in Lebanon, Eastern Mediterranean. Mar. Geol. 230, 99-114, doi:10.1016/j.margeo.2006.04.003, 2006.

Nocquet, J.-M.: Present-day kinematics of the Mediterranean: A comprehensive overview of GPS results. Tectonophysics 579, 220-242, doi:10.1016/j.tecto.2012.03.037, 2012.

505 Ott, R.F., Gallen, S.F., Wegmann, K.W., Biswas, R.H., Herman, F. and Willett, S.D.: Pleistocene terrace formation, Quaternary rock uplift rates and geodynamics of the Hellenic Subduction Zone revealed from dating of paleoshorelines on Crete, Greece. Earth Plan. Sci. Lett. 525, 115757, https://doi.org/10.1016/j.eps1.2019.115757, 2019.

Ozalp, H.B., Alparslan, M.: Scleractinian diversity in the Dardanelles and Marmara Sea (Turkey): morphology, ecology and distributional patterns. Oceanological and Hydrobiological Studies 45, 259-285, DOI: 10.1515/ohs-2016-0023, 2016. 
510 Palamakumbura, R. N., Robertson, A. H., Kinnaird, T. C., van Calsteren, P., Kroon, D.,and Tait, J. A.: Quantitative dating of Pleistocene deposits of the Kyrenia Range, northern Cyprus: implications for timing, rates of uplift and driving mechanisms. Journal of the Geological Society, 173(6), 933-948, doi:10.1144/jgs2015-130, 2016.

Parham, P.R., Riggs, S.R., Culver, S.J., Mallinson, D.J., Wehmiller, J.F.: Quaternary depositional patterns and sea-lever fluctuations, northeastern North Carolina. Quat. Res. 67, 83-99, doi:10.1016/j.yqres.2006.07.003, 2007.

515 Paskoff, R., Sanlaville, P., 1983. Les côtes de la Tunisie. Variations du niveau marin depuis le Tyrrénien. Coll. Maison de l'Orient, Lyon. 14, 192p.

Peirano, A., Kružić, P., Mastronuzzi, G.: Growth of Mediterranean reef of Cladocora caespitosa (L.) in the Late Quaternary and climate inferences. Facies 55, 325-333, DOI 10.1007/s10347-008-0177-x, 2009.

Poole A.J., and Robertson, A.H.F.: Quaternary uplift and sea-level changes at active plate boundary, Cyprus, Journal of Geological Society, London 148, 909-921, 1991.

Poole, A.J., Robertson, A.H.F., and Shimmield, G.: Late Quaternary uplift of the Troodos ophiolite, Cyprus; Uranium-series dating of Pleistocene coral. Geology 18, 894-897, 1990.

Porat, N., Avital, A., Frechen, M. and Almogi-Labin, A.: Chronology of upper Quaternary offshore successions from the southeastern Mediterranean Sea, Israel. Quat. Sci. Rev. 22, 1191-1199, doi:10.1016/S0277-3791(03)00016-7, 2003.

525 Queslati, A.:Salt marshes in the Gulf of Gabes (southeastern Tunisia): Their morphology and recent dynamics. J. Coast. Res. 8(3), 727-733, 1992.

Reading, H.G.: Sedimentary environments and facies. Blackwell Scientific Publications, London, 1986.

Robertson, J., M. Meschis, G. P. Roberts, A. Ganas, D. M. Gheorghiu: Temporally constant Quaternary uplift rates and their relationship with extensional upper-plate faults in south Crete (Greece), constrained with ${ }^{36} \mathrm{Cl}$ cosmogenic exposure dating. Tectonics 38, 1189-1222, DOI:10.1029/2018TC005410, 2019.

Rodolfo-Metalpa, R., A. Peirano Æ F. Houlbreque, M. Abbate, C. Ferrier-Pages: Effects of temperature, light and heterotrophy on the growth rate and budding of the temperate coral Cladocora caespitose. Coral Reefs 27, 17-25, DOI 10.1007/s00338-007-0283-1, 2008.

Rovere, A. Raymo, M.E., Vacchi, M., Lorscheid, T., Stocchi, P., Gomez-Pujol, L., Harris, D.L., Casella, E., O’Leary, M.J. and Hearty, P.: The analysis of Last Interglacial (MIS 5e) relative sea-level indicators: Reconstructing sea level in a warmer world. Earth-Sci. Rev. 159, 404-427, http://dx.doi.org/10.1016/j.earscirev.2016.06.006, 2016.

Rovere, A., Ryan, D., Murray-Wallace, C., Simms, A., Vacchi, M., Dutton, A., Lorscheid, T., Chutcharavan, P., Brill, D., Bartz, M., Jankowski, N. Mueller, D., Cohen, K. and Gowan, E.: Description of database fields for the Word Atlas of last interglacial shorelines (WALIS). Zenodo, version 1, http://doi.org/10.5281/zenodo.3961544, 2020.

540 Sessa, J.A., Callapez, P.M., Dinis, P.A., Hendy, A.J.W.: Paleoenvironmental and paleobiogeographical implications of a middle Pleistocene mollusc assemblage from the marine terraces of Baía das Pipas, Southwest Angola. J Paleont. 87(6), 1016-1040, D1016S03.00 DO1: 10.1666/12-119, 2013.

Shennan, I.: Flandrian sea-level changes in the Fenland. II: tendencies of sea-level movement, altitudinal changes, and local and regional factors. J. Quat. Sci.1, 155-179, https://doi.org/10.1002/jqs.3390010205, 1986.

545 Shennan, I., Long, A.J., Horton, B.P. (Eds,), Handbook of sea-level research. John Wiley \& Sons, Ltd, Chichester, 2015.

Sisma-Ventura, G., Sivan, D., Shtienberg, G., Bialik, O.M., Filin, S., Greenbaum, N.: Last interglacial sea level highstand deduced from well-preserved abrasive notches exposed on the Galilee coast of northern Israel. Palaeo-3 470, 1-10, http://dx.doi.org/10.1016/j.palaeo.2017.01.008, 2017. 
Sivan, D. and Galili, E.: The last interglacial sea-level record of the Israeli coastline - WALIS database of sea-level indicators [Data set]. Zenodo. http://doi.org/10.5281/zenodo.4274178, 2020.

Sivan D., Sisma-Ventura G., Greenbaum N., Bialik O.M., Williams, F.H., Tamisiea,M.E,, Rohling, E.J., Frumkin, A., Avnaim-Katav S., Shtienberg G., Stein M.: Eastern Mediterranean sea levels through the last interglacial from a coastalmarine sequence in northern Israel. Quaternary Science Reviews 145, 204-225, http://dx.doi.org/10.1016/j.quascirev.2016.06.001, 2016.

555 Sivan, D., Gvirtzman, G. and Sass, E.: Quaternary Stratigraphy and Paleogeography of the Galilee Coastal Plain, Israel. Quaternary Research 51, 280-294, qres.1999.2044, 1999.

Tari, U., Okan Tüysüz, Bonnie A.B. Blackwell, Zarrin Mahmud, Jonathan A. Florentin, Justin Qi, Ş. Can Genç, Anne R. Skinner: Seal level change and tectonic uplift from dated marine terraces along the eastern Mediterranean coast, southeastern Turkey. Palaeo-3 511, 80-102, https://doi.org/10.1016/j.palaeo.2018.07.003, 2018.

Trotter, J., Montagna, P., McCulloch, M., Silenzi, S., Reynaud, S., Mortimer, G., Martin, S., Ferrier-Pagès, C., Gattuso, J.-P. and Rodolfo-Metalpa, R.: Quantifying the $\mathrm{pH}$ 'vital effect' in the temperate zooxanthellate coral Cladocora caespitosa: Validation of the boron seawater pH proxy. Earth Plan. Sci. Lett. 303, 163-173, doi:10.1016/j.eps1.2011.01.030, 2011.

van de Plassche, O. (ed): Sea-level research: A Manual for the collection and evaluation of data. Geo Books, Norwich, 1986.

van der Meer, F. and Cloetingh, S.: Intraplate stresses and the subsidence history of the Sirte Basin (Libya). Tectonophysics 226, 37-58, 1993.

Vescogni, A., Francesca R. Bosellini, Markus Reuter, Thomas C. Brachert: Vermetid reefs and their use as palaeobathymetric markers: New insights from the Late Miocene of the Mediterranean (Southern Italy, Crete). Palaeo-3 267, 89-101, doi:10.1016/j.palaeo.2008.06.008, 2008.

Vita-Finzi, C.: ${ }^{14} \mathrm{C}$ dating of Late Quaternary uplift in western Cyprus. Tectonophysics, 172, 135-140 1990.

570 Vita-Finzi, C.: Evaluating Late Quaternary uplift in Greece and Cyprus. In: Prichard, H. M., Alabaster, T., Harris, N. B.W. and Neary, C. R. (eds), Magmatic Processes and Plate Tectonics. Geological Society, London, Special Publications, 76, 417-424, http://doi.org/10.1144/GSL.SP.1993.076.01.21, 1993.

Weinberger, R., Gross, M.R. and Sneh, A.: Evolving deformation along a transform plate boundary: Example from the Dead Sea Fault in northern Israel. Tectonics 28, TC5005, doi:10.1029/2008TC002316, 2009.

575 Wided, S., Jalila, S. and Kamel, R.: Sedimentology and high-frequency cycles of the late Pleistocene of the Bizerte area (NE Tunisia). Arab. J. of Geosci., https://doi.org/10.1007/s12517-019-4719-z, 2019.

Yaltirak, C., Sakinc, M., Aksu, A.E., Hiscott, R.N., Galleb, B. and Ulgen, U.B.: Late Pleistocene uplift history along the southwestern Marmara Sea determined from raised coastal deposits and global sea-level variations. Mar. Geol. 190, 283305.

580 Zomeni, Z.: Quaternary Marine Terraces on Cyprus: Constraints on Uplift and Pedogenesis, and the Geoarchaeology of Palaipafos. PhD thesis, Oregon State University, https://ir.library.oregonstate.edu/concern/graduate_thesis_or_dissertations/z603r1518?locale=en, 2012.

Zviely, D., Sivan, D., Ecker, A., Bakler, N., Rohrlich, V., Galili, E., Boaretto, E., Klein, M. and Kit, E.: Holocene evolution of the Haifa Bay area, Israel, and its influence on ancient tell settlements. The Holocene 16(6), 849-861, 10.1191/0959683606hol977rp, 2006. 